\title{
Implementasi Pendekatan Bermain Dalam Pembelajaran Aktivitas Berlari
}

\author{
Bisri Musthofa $^{1}$, Toto Subroto ${ }^{2}$, Dian Budiana ${ }^{3}$
}

\begin{abstract}
Abstrak
Penelitian ini bertujuan untuk memperbaiki proses pembelajaran PJOK, khususnya pembelajaran aktivitas berlari melalui implementasi pendekatan bermain. Metode penelitian yang digunakan adalah Penelitian Tindakan Kelas (PTK) yang dilaksanakan selama dua siklus. Siklus pertama terdiri atas tiga tindakan, siklus kedua terdiri atas dua tindakan.Setiap siklus dan tindakan dilakukan melalui empat tahapan, yaitu: perencanaan, pelaksanaan, observasi dan refleksi. Subjek penelitian adalah siswa kelas VII D di SMP Negeri 2 Sindang Kabupaten Indramayu. Teknik pengumpulan data yang dilakukan dalam penelitian ini adalah observasi, catatan lapangan, catatan observer, dan catatan hasil diskusi. Jenis data yang diperoleh adalah data kualitatif dan data kuantitatif. Data kualitatif berupa deskripsi kualitatif tentang pelaksanaan tindakan. Data kuantitatif berupa hasil belajar siswa. Teknik analisis data kualitatif digunakan teknik trianggulasi. Teknik analisis data kuantitatif digunakan teknik perhitungan rata-rata. Hasil penelitian menunjukan bahwa (1) peneliti sudah mampu mengimplementasikan model pembelajaran pendekatan bermain dan sudah mampu menghadapi kesulitan ketika pelaksanaan tindakan seperti mengondisikan siswa, menyampaikan materi dengan jelas, menilai hasil belajar siswa., (2) rata-rata hasil belajar siswa menunjukan peningkatan dari mulai tindakan ke 1 (69 afektif, 87 kognitif, 67 psikomotor) sampai dengan tindakan ke 5 (97 afektif, 87 kognitif, 74 psikomotor). Berdasarkan hasil penelitian ini maka, maka dapat disimpulkan bahwa pendekatan bermain dapat diterapkan dan dilaksanakan dalam pembelajaran aktivitas berlari.
\end{abstract}

Kata Kunci: Pendekatan Bermain, Aktivitas Berlari. 


\title{
The Implementation of Play Approach in Run Activity Learning
}

\author{
Bisri Musthofa ${ }^{1}$, Toto Subroto ${ }^{2}$, Dian Budiana ${ }^{3}$
}

\begin{abstract}
The research purpose is to improve PJOK learning process, in particular at run activity learning through the implementation of play approach. Research method used in this research is classroom action research which is used in two cycles. The first cycles consist of three actions and the second cycles consist of two actions. Each cycles and actions is done by four steps. They are planning, implementation, observation and reflection. The research subject is the students of Junior High School in VIID Class at SMP N 2 Sindang Indramayu. The Technique of collecting data used in this research is observation, field note, observer note, and discussion result note. Kind of data that is obtained from the research is qualitative and quantitative data. The qualitative data used in this research is the qualitative description about the implementation of the action. The quantitative data used in this research is the student learning result. This Research uses triangulation technique to analyze the qualitative data and uses the technique of means calculation to analyze the quantitative data. The research results show that (1) the researcher was capable to implement the learning model of play approach and was capable to face the difficulty when researcher implements the actions such as controlling student, delivering learning content clearly, and assessing learning result of the student., (2) according to average of student learning result, it shows the enhancement start from the first action (69 affectives, 87 cognitives, 67 psychomotors) until the fifth action ( 97 affectives, 87 cognitives, 74 psychomotors). Based on the research result, it can be concluded that play approach can be applied and can be done in run activity learning.
\end{abstract}

Keywords : Play Approach, Run Activity. 


\section{PENDAHULUAN}

Gerak berlari merupakan salah satu gerak dasar manusia.MenurutSukintaka (1992, hlm. 53) "Lari merupakan pengembangan berjalan, dan mempunyai sifat khusus, ialah badan pada suatu saat tidak ada kontak dengan tanah atau tidak bertumpu pada tanah.Tentu saja pada saat melayang atau tidak ada kontak dengan tanah ini, badan dalam keadaan yang kurang stabil".Dikatakan sebagai pengembangan berjalan karena lari merupakan gerak berjalan yang dilakukan secara cepat.Jadi, kalimat pengembangan berjalan dapat diartikan bahwa berjalan dan berlari itu adalah gerak dasar berjalan yang di percepat dari satu titik ke titik lainnya.

Gerak berlari digunakan oleh manusia untuk mencapai tujuan tujuan yang sederhana sampai kepada tujuan - tujuan yang lebih kompleks.Gerak lari yang digunakan dalam mencapai tujuan yang sederhana misalnya ketika digunakan dan dibutuhkan untuk menyelamatkan diri, berburu makanan atau digunakan ketika bermain dengan temannya menggunakan salah satu gerak.Gerak berlari di gunakan manusia untuk tujuan - tujuan yang lebih kompleks, misalnya untuk memenuhi derajat kesehatan. Intensitas dan volume yang tepat dapat meningkatkan kebugaran jasmani, berlari yang teratur dengan porsi tertentu serta dilakukan secara berkelanjutan akan baik untuk kesehatan. Dengan berlari daya tahan kardiovaskular akan meningkat, meningkatkan daya tahan serta menjaga kebugaran jasmani agar tetap baik. Selain itu aktivitas berlari juga akan membentuk otot-otot menjadi lebih baik.

Aktivitas berlari juga dilakukan untuk tujuan prestasi, memerlukan proses latihan sesuai dengan prinsip - prinsip dan metode latihan yang baik dan benar. 
Begitu pentingnya gerak dasar berlari bagi kehidupan manusia terutama untuk menigkatkan kualitas gerak, maka didalam pembelajaran pendidikan jasmani olahraga dan kesehatan (PJOK) aktivitas gerak berlari sudah dijadikan bagian dari pembelajaran mulai dari sekolah dasar sampai sekolah menengah atas. Dalam kurikulum pendidikan jasmani olahraga dan kesehatan (PJOK) tahun 2013, pembelajaran aktivitas berlari termasuk ke dalam kelompok aktivitas pembelajaran gerak dasar lokomotor. Kompetensi yang harus dimiliki siswa selama atau dan setelah pembelajaran aktivitas gerak dasar lokomotor, yang di maksud kompetensi menurut Spencer \& Spencer dalam Palan (2007, hlm. 6) mengemukakan bahwa kompetensi merujuk kepada karakteristik yang mendasari perilaku yang menggambarkan motif, karakteristik pribadi (ciri khas), konsep diri, nilai-nilai, pengetahuan atau keahlian yang dibawa seseorang yang berkinerja unggul (superior performer) di tempat kerja. Untuk memperoleh kompetensi tersebut di perlukan model, pendekatan, strategi pembelajaran tertentu, yang didukung oleh sarana, prasarana dan alat alat pembelajararan yang relevan.

Dalam kurikulum 2013 pendekatan pembelajaran yang ditekankan atau digunakan dalam pembelajaran aktivitas berlari adalah pendekatan bermain. Digunakannya pendekatan bermain, mungkin akan membentuk karakteristik anak lebih suka bermain, sehingga membuat pembelajaran aktivitas berlari tidak cepat membosankan bagi anak.

Menurut Wina (2009, hlm. 125) pendekatan pembelajaran dapat diartikan sebagai titik tolak atau sudut pandang kita terhadap proses pembelajaran, Sedangkanmenurut Sukintaka (1992, hlm. 37) menyatakan bahwa "bermain adalah aktivitas jasmani yang dilakukan dengan sukarela 
dan bersungguh-sungguh untuk memperoleh rasa senang dari melakukan aktivitas tersebut."

Dengan demikian yang dimaksud dengan pendekatan bermain dalam penelitian ini adalah sebuah pembelajaran PJOK yang harus dilandasi dan dilakukan dalam kondisi sukarela dan bersungguh sungguh untuk memperoleh rasa senang dalam melakukan aktivitas tersebut.Sukarela, sungguh - sungguh dan rasa senang merupakan ciri dalam pendekatan bermain dalam sebuah pembelajaran.Melalui penerapan pendekatan pembelajaran yang di landasi oleh prisnsip tersebut, diharapkan motivasi belajar yang tinggi yang pada gilirannya waktu aktif belajarnya tinggi.

Berdasarkan pemaparan di atas bahwa dalam proses pembelajaran pendidikan jasmani, implementasi pendekatan bermain dapat memperbaiki proses pembelajaran PJOK khususnya pembelajaran aktivitas berlari, dan dapat meningkatkan motivasi peserta didik dalam melakukan aktivitas pembelajaran PJOK.

\section{METODE PENELITIAN}

\section{A. Desain Penelitian}

Desain penelitian merupakan cara atau metode yang ditempuh dalam penelitian, sehingga rumusan masalah dan hipotesis yang akan diajukan dapat dijawab dan diuji secara akurat. penelitian yang diggunakan adalah penelitian tindakan kelas (Classroom Action Research). Metode penelitian tindakan kelas (PTK) adalah sebuah kajian sistematik tentang upaya meningkatkan mutu praktik pembelajaran oleh sekelompok masyarakat melalui tindakan praktis dan refleksi atas hasil tindakan tersebut. Arikunto 
(2013, hlm. 203) menjelaskan bahwa "Metode penelitian adalah cara yang digunakan oleh peneliti dalam mengumpulkan data penelitiannya”.

\section{B. Partisipan dan Tempat Penelitian}

Partisipan sebagai subjek penelitian yang penulis teliti adalah siswa $\begin{array}{lllllll}\text { kelas VII D di } & \text { SMP Negeri } 2 \text { Sindang Kabupaten }\end{array}$ Indramayu.sebanyak35siswa, terdiri dari 18 siswa laki-laki dan17 siswa perempuan. Tempat penelitian tindakan kelas ini dilaksanakan di SMP Negeri 2 Sindang Kabupaten Indramayu yang beralamat di Jl. Murah Nara No. 5 Kabupaten Indramayu.

\section{Pengumpulan Data}

Teknik pengumpulan data merupakan langkah yang paling utama dalam penelitian.Jenis data dalam penelitian ini berupa data deskriptif kualitatif tentang permasalahan dan cara pemecahan masalah, yang teridentifikasi oleh peneliti selama proses penelitian, alat yang di gunakan adalah dalam bentuk catatan observer, lembar penilaian, catatan lapangan dan alat dokumentasi.

\section{Analisis Data}

Analisis data merupakan bagian yang sangat penting dari suatu penelitian.Oleh sebab itu, peneliti harus memahami teknik analisis data agar hasil penelitiannya mempunyai nilai ilmiah yang baik. Dalam penelitian ini analisis data yang di gunakan adalah trianggulasi kualitatif yakni sebagi berikut: PTK ada dua jenis data yang dapat dikumpulkan dan dianalisis, yaitu : data berupa kalimat yang diperoleh saat proses pembelajaran dan wawancara yang berhubungan dengan pandangan atau 
sikap siswa, antusiasme siswa dalam belajar, motivasi siswa. Data jenis ini dapat dianalisis secara kualitatif.

Setelah data terkumpul dianalisis dengan menggunakan teknik kualitatif supaya diperoleh data yang sesuai dengan fokus masalah. Data tersebut meliputi perkataan, tindakan peristiwa yang diamati (observasi) selama proses pelaksanaan pembelajaran pendidikan jasmani berlangsung. Secara garis besar analisis data dapat dilakukan dengan langkah-langkah sebagai berikut:

a. Menelaah seluruh data yang dikumpulkan. Baik dari data hasil observasi lapangan maupun data yang berupa dokumentasi. Penelaahan dilakukan dengan cara "Triangulasi", yaitu menganalisis, mensintetis, memaknai, menerangkan dan menyimpulkan data yang terkumpul bersama-sama guru penjas, peneliti, dan pembimbing skripsi.

b. Mereduksi data yang didalamnya melibatkan pengkatagorian dan mengklarifikasikan.

c. Menyimpulkan dan memverifikasi.

\section{HASIL PENELITIAN}

Berdasarkan analisis di lapangan implementasi pendekatan bermain dalam pembelajaran aktivitas berlari di SMP Negeri 2 Sindang Kabupaten Indramayu, menghasilkan perubahan sikap, pemahaman, dan keterampilan siswa menjadi lebih baik dari sebelumnya.Hal ini dibuktikan dengan meningkatnya hasil belajar siswa dari aspek afektif, aspek kognitif, dan aspek psikomotor. 


\section{Tabel 4.9}

\section{Grafik Peningkatan Hasil Belajar Pada 3 Aspek (Afektif, Kognititf, Psikomotorik) dalam Pembelajaran Aktivitas Berlari}

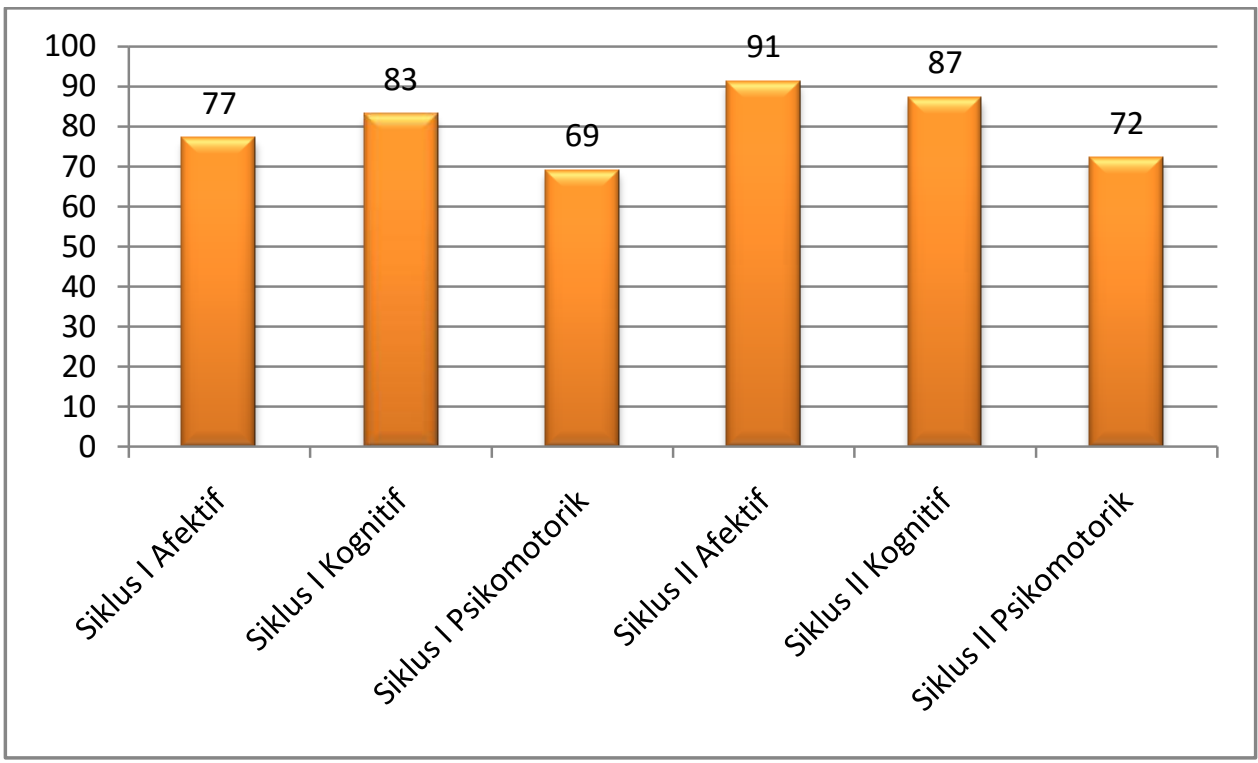

Pada Grafik diatas dapat dilihat di siklus I dengan nilai rata-rata aspek afektif yaitu 77, aspek kognitif yaitu 83, dan aspek psikomotor yaitu 69. Sedangkan siklus II dengan nilai rata-rata aspek afektif yaitu 91, aspek kognitif yaitu 87, dan aspek psikomotor yaitu 72.Secara keseluruhan hasil belajar dari tiga aspek (afektif, kognitif, psikomotor) dari siklus I sampai dengan siklus II terjadi peningkatan.

\section{KESIMPULAN}

Berdasarkan hasil analisis data penelitian yang penulis teliti terbukti bahwa pendekatan bermain dapat diterapkan dan dilaksanakan dalam pembelajaran aktivitas berlari. 


\section{DAFTAR PUSTAKA}

Peraturan Menteri Pendidikan Nasional Republik Indonesia Nomor 22 Tahun 2006 Tentang Standar Isi untuk Satuan Pendidikan Dasar dan Menengah.

Peraturan Menteri Pendidikan dan Kebudayaan Republik Indonesia Nomor 68 Tahun 2013 tentang Kerangka Dasar dan Struktur Kurikulum Sekolah Menengah Pertama/Madrasah Tsanawiyah.

Sanjaya, W. (2009).Strategi Pembelajaran Berorientasi Standar Proses Pendidikan. Bandung: Kencana.

Sukintaka.(1992). Teori Bermain.Bandung : Departemen Pendidikan dan Kebudayaan.

Tim Pelatih Proyek PGSM. (1999). Penelitian Tindakan Kelas. Bandung: Tut Wuri Handayani.

Sumber dari internet :

Palan.(2007). Pengetian Kompetensi. [online]. Diakses dari http://ariplie.blogspot.co.id/2015/04/pengertian-dan-konsep-kompetensi.html 